\title{
Production of Pearl Millet Irrigated with Different Levels of Brackish Water and Organic Matter
}

\author{
Jaciele Beserra de Lira, Alberício Pereira de Andrade, André Luiz Rodrigues Magalhães, \\ Fleming Sena Campos, Gherman Garcia Leal de Araújo, Diana Signor Deon, \\ Glayciane Costa Gois, Amadeu Regitano Neto, Diego de Sousa Cunha, José Nildo Tabosa, \\ Thieres George Freire da Silva, and Hideo de Jesus Nagahama
}

aFederal Rural University of Pernambuco, Garanhuns, Brazil; 'brazilian Agricultural Research Corporation, Petrolina, Brazil; 'Federal University of Vale do São Francisco, Petrolina, Brazil; ${ }^{d}$ Agronomic Institute of Pernambuco, Recife, Brazil; eFederal Rural University of Pernambuco, Talhada, Brazil

\begin{abstract}
The objective is to determine the growth, yield and chemical characteristics of pearl millet irrigated with different levels of brackish water and organic matter in two cultivation cycles. The experimental design was randomized blocks in a $4 \times 4$ factorial arrangement, composed of 4 levels of brackish irrigation (25, 50, 75 and $100 \%$ evapotranspiration), 4 levels of organic matter $(0,15,30$ and $45 \mathrm{t} \mathrm{ha}^{-1}$ ) with 3 repetitions. Along two cultivation cycles, pearl millet crop was analyzed for: plant growth variables, fresh and dry mass production, water-use efficiency, and chemical composition. There was significant interaction between applied water levels and organic matter for lignin in the 2 nd cut $(P<.05)$. The number of leaves, number of dead leaves and fresh mass production were influenced by the isolated effect of brackish water levels in cut $1(P<.05)$. In turn, fresh mass production, dry mass production, plant height, leaves length, panicle length, fresh mass production, crude protein and ether extract were influenced by the isolated effect of saline water levels in the 2nd cut $(P<.05)$. Growth, biomass production and chemical composition variables in second cut are positively influenced by different brackish irrigation levels under low rainfall conditions.
\end{abstract}

\section{ARTICLE HISTORY}

Received 16 December 2019

Accepted 16 January 2020

\section{KEYWORDS}

Brackish water; irrigation; organic matter; Pennisetum glaucum

\section{Introduction}

The Brazilian Northeast region has about 1.56 million $\mathrm{km}^{2}$, accounting for $18.2 \%$ of the country, housing almost entirely the Semiarid region. It is strongly influenced by a negative water balance coming from low annual mean precipitations of around $800 \mathrm{~mm}$ and annual mean temperatures from 23 to $27^{\circ} \mathrm{C}$, with an evaporation of $2000 \mathrm{~mm}$ /year, mean relative air humidity around $50 \%$, and mean insolation of 2800 hour/year. Because of these characteristics and a regime of irregular and scarce precipitations, water sources are considered insufficient in the region (Gois et al. 2019).

Salinity is more severe in the arid and semi-arid regions of the world, characterized by low and irregular rainfall, high temperatures and high evapotranspiration. Due to the high salt concentrations, these waters are often considered unsuitable for human consumption and animal watering, requiring alternative measures for their use, such as irrigation of plants more tolerant to salinity (Shrivastava and Kumar 2015; Sjoerd et al. 2017).

One of the techniques used for cultivation of plants in saline environments is the use of resistant and adapted species, such as pearl millet, highlighting its ability to adapt to saline environments and semi-arid conditions. Investigations have shown that crop respond differently to salinity, some produce economically acceptable yields under high salinity levels, while others are sensitive to 
relatively low levels. This fact is due to the better capacity of osmotic adaptation of plants, which allows absorption of sufficient water, even in a saline medium (Taiz et al. 2017; Toderich et al. 2018; Travassos et al. 2019).

One of the techniques used for cultivation of plants in saline environments is the use of resistant and adapted species, such as pearl millet, highlighting its ability to adapt to saline environments and semi-arid conditions. Pearl millet has high biomass productivity, agronomic and nutritional characteristics necessary for use as forage, has adequate nutritional quality for the production of hay, silage and fresh consumption (Moura et al. 2018).

The objective was to evaluate growth variables, biomass production, water use efficiency and chemical characterization of pearl millet (ADR 300) under different irrigation levels, associated with the levels of organic fertilization.

\section{Material and methods}

\section{Location and meteorological data}

The study was carried out in the Area of Prospection and Studies on Biosaline Agriculture of the Caatinga Experimental Field, belonging to Embrapa Semiarid, Petrolina, State of Pernambuco, in the sub-middle region of São Francisco (latitude $9^{\circ} 8^{\prime}$ 8,9” S, longitude $40^{\circ} 18^{\prime} 33,6^{\prime \prime} \mathrm{W}, 373 \mathrm{~m}$ altitude). The climate of the region is classified, according to Köppen, as BSwh' semi-arid, with average annual rainfall around $400 \mathrm{~mm}$, unevenly distributed (Figure 1).

\section{Soil and water chemical composition}

The soil of the experimental area is classified as Red Yellow Argisol (Santos et al. 2013) situated in a flat relief, medium texture. The chemical characteristics are listed in Table 1.

The water used for irrigation came from underground wells, and a weekly sample was collected for physicochemical analysis (Table 2), aiming at possible variations, a fact that did not occur during the experimental period. Irrigation was performed daily, by dripping containing emitters with flow rate of $1.6 \mathrm{~L} \mathrm{~h}^{-1}$, spaced $0.20 \mathrm{~m}$ apart. Water used for irrigation was identified as C3S1, i.e. with high salinity, low sodium content and moderate hardness $(75-150 \mathrm{mg} / \mathrm{L})$ based on calcium carbonate (Richard 1954). Irrigation levels equivalent to $25,50,75$ and $100 \%$ evapotranspiration during the 63 days before the first cut were $49.67 ; 81.85 ; 114.02 ; 146.20 \mathrm{~mm}$, respectively, and along the 46 days preceding the second cut, the depths applied were 40.29; 80.59; 120.89 and $161.18 \mathrm{~mm}$ (Figure 1b).
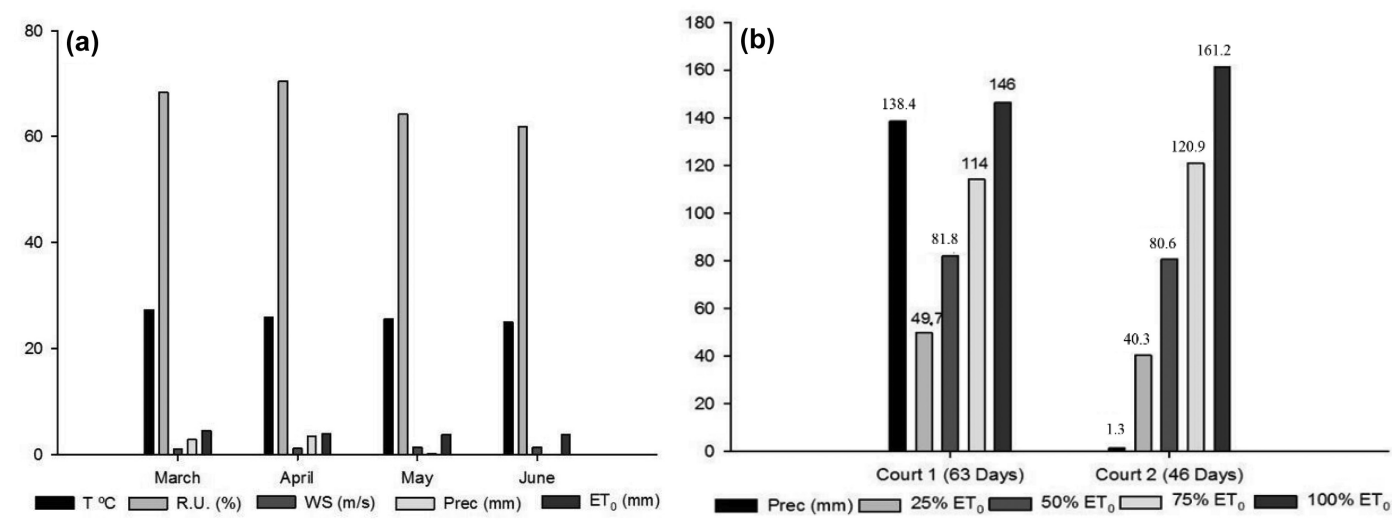

Figure 1. Monthly agrometeorological data (a) and irrigation levels applied to treatments compared to rainfall (b) during the experimental period. 
Table 1. Soil chemical composition of the experimental area.

\begin{tabular}{llccccc}
\hline & \multicolumn{5}{c}{ Sample identification } \\
\cline { 2 - 6 } Variable & & $0-20$ & $20-40$ & $40-60$ & $60-80$ & $80-100$ \\
\hline $\mathrm{EC}$ & $\mathrm{mScm}^{-1}$ & 1.33 & 2.20 & 2.41 & 2.50 & 2.60 \\
$\mathrm{pH}$ & - & 4.6 & 5.7 & 5.0 & 4.5 & 4.5 \\
Total C & $\mathrm{g} \mathrm{Kg}^{-1}$ & 4.6 & 4.1 & 3.7 & 2.3 & 2.1 \\
$\mathrm{P}$ & $\mathrm{Mgdm}^{-3}$ & 6.14 & 1.22 & 0.55 & 1.69 & 0.21 \\
$\mathrm{~K}$ & $\mathrm{Cmol} \mathrm{dm}^{-3}$ & 0.23 & 0.16 & 0.15 & 0.11 & 0.08 \\
$\mathrm{Na}$ & $\mathrm{Cmol} \mathrm{dm}^{-3}$ & 0.27 & 0.68 & 1.12 & 1.40 & 1.18 \\
$\mathrm{Ca}$ & $\mathrm{Cmol} \mathrm{dm}^{-3}$ & 1.6 & 1.4 & 2.4 & 2.8 & 3.2 \\
$\mathrm{Mg}$ & $\mathrm{Cmol} \mathrm{dm}^{-3}$ & 0.60 & 0.60 & 1.50 & 2.20 & 2.00 \\
$\mathrm{Al}$ & $\mathrm{Cmol} \mathrm{dm}^{-3}$ & 0.05 & 0.00 & 0.20 & 015 & 0.05 \\
$\mathrm{H}+\mathrm{Al}$ & $\mathrm{Cmol} \mathrm{dm}^{-3}$ & 1.5 & 2.7 & 2.5 & 2.3 & 2.3 \\
$\mathrm{SB}$ & $\mathrm{Cmol} \mathrm{dm}^{-3}$ & 2.7 & 2.8 & 5.2 & 6.5 & 6.5 \\
$\mathrm{CEC}$ & $\mathrm{Cmol} \mathrm{dm}^{-3}$ & 4.2 & 5.6 & 7.7 & 8.8 & 8.7 \\
$\mathrm{~V}$ & $\%$ & 54.0 & 50.9 & 67.4 & 74.3 & 74.2 \\
$\mathrm{Cu}$ & $\mathrm{Mgdm}^{-3}$ & 1.07 & 1.65 & 1.49 & 1.37 & 1.18 \\
$\mathrm{Fe}$ & $\mathrm{Mgdm}^{-3}$ & 21.4 & 23.0 & 8.5 & 6.0 & 9.5 \\
$\mathrm{Mn}$ & $\mathrm{Mgdm}^{-3}$ & 18.2 & 14.6 & 12.9 & 7.0 & 8.1 \\
$\mathrm{Zn}$ & $\mathrm{Mgdm}^{-3}$ & 4.54 & 3.13 & 2.07 & 2.05 & 2.82 \\
\hline
\end{tabular}

$\mathrm{EC}=$ electrical conductivity of the saturation extract; $\mathrm{pH}$ determined in water at a ratio of 1:2.5; Total $\mathrm{C}=$ Total carbon; $P=$ available phosphorus extracted by Mehlich; $\mathrm{K}=$ exchangeable potassium; $\mathrm{Na}=$ exchangeable sodium; $\mathrm{Ca}=$ exchangeable calcium; $\mathrm{Mg}=$ exchangeable magnesium; $\mathrm{Al}=$ exchangeable aluminum; $\mathrm{H}+\mathrm{Al}=$ Potential acidity; $\mathrm{SB}=$ Sum of bases; $\mathrm{CEC}=$ cation exchange capacity at $\mathrm{pH} 7.0 ; \mathrm{V}=$ base saturation; $\mathrm{Cu}=$ available Copper; $\mathrm{Fe}=$ available Iron; $\mathrm{Mn}=$ available Manganese; $\mathrm{Zn}=$ available Zinc.

Table 2. Chemical analysis of the artesian well water of the caatinga experimental field.

\begin{tabular}{|c|c|c|c|c|c|c|c|c|}
\hline \multicolumn{6}{|c|}{$\mathrm{mmol}^{-\mathrm{L}^{-1}}$} & \multirow{2}{*}{$\frac{\mathrm{ds} \mathrm{m}^{-1}}{\mathrm{EC}}$} & \multirow{2}{*}{$\frac{\mathrm{mg} \cdot \mathrm{L}^{-1}}{\mathrm{TH}}$} & \multirow[b]{2}{*}{ SAR } \\
\hline $\mathrm{Ca}^{2+}$ & $\mathrm{Mg}^{2+}$ & $\mathrm{Na}^{+}$ & $\mathrm{K}^{+}$ & $\mathrm{Cl}^{-}$ & $\mathrm{pH}$ & & & \\
\hline 15.14 & 6.89 & 3.72 & 0.29 & 22.04 & 7.38 & 1.73 & 109.76 & 0.62 \\
\hline
\end{tabular}

The organic matter used was a cattle compost, with the following characteristics: $\mathrm{EC}=12.27 \mathrm{mS}$. $\mathrm{cm}^{-1} ; \mathrm{pH}=8.3$; Phosphorus $=355.39 ;$ Potassium $=243.5$; Sodium $=20.3$; Calcium $=6.4$ and Magnesium $=2.5 \mathrm{cmolc} . \mathrm{dm}^{-3}$; while for Copper, Iron, Manganese and Zinc, the observed values were $1.45 ; 5.36 ; 58.13$ and $2.43 \mathrm{mg} \mathrm{dm}^{-3}$, respectively.

\section{Experimental design}

The experimental design was randomized blocks in a $4 \times 4$ factorial arrangement, composed of four levels of brackish irrigation (L1 - 25, L2 - 50, L3 - 75 and L4 - 100\% evapotranspiration), four levels of organic matter $\left(0,15,30\right.$ and $\left.45 \mathrm{t} \mathrm{ha}^{-1}\right)$ with three replications. Each experimental subplot consisted of 6 planting rows, 4 meters long by 3.6 meters wide and $0.60 \mathrm{~cm}$ between rows, totaling 48 subplots. Millet (ADR 300) sowing was performed in furrows, with an average of $40 \mathrm{seeds} / \mathrm{m}$, at a depth of approximately $1.0 \mathrm{~cm}$. At 15 days after emergence, thinning was performed to allow 15 plants/m.

Four plants were evaluated per subplot, located in the central rows. The variables: plant height, leaf number, stem base diameter, leaf length, panicle length and panicle diameter were measured with a measuring tape and digital caliper. Measurements were taken at the end of the first and second cuts.

For proportion of plant parts, four plants were randomly selected per subplot and separated into the components: stem, leaf blade, panicle and dead material (senescent leaves), placed in identified, weighed bags and oven-dried for 72 hours in a forced ventilation at $55^{\circ} \mathrm{C}$, and then weighed to determine the proportion of plant parts on a dry matter basis. 
Fresh matter production per hectare was obtained by the product between the production per cultivated linear meter and the total cultivated linear meters per hectare. Dry matter production was estimated by the product between green matter production and dry matter content and was expressed as dry matter production per hectare.

After initial weighing of the collected material, it was oven-dried at $55^{\circ} \mathrm{C}$ for 72 hours, and then weighed to obtain the dry matter values. Then, the values obtained from fresh matter and dry matter were expressed in megagrams per hectare $\left(\mathrm{Mg} \mathrm{ha}^{-1}\right)$. Water use efficiency was estimated by dividing the dry matter weight by the amount of water accumulated during the cycle (Ertek, Sensoy, and Gedik 2006).

\section{Chemical composition}

After drying, the samples were ground in a Wiley mill (Marconi, MA - 580, Piracicaba, Brazil) with $2 \mathrm{~mm}$ and $1 \mathrm{~mm}$ sieves. Analyzes for dry matter (DM; method 967.03), mineral matter (MM; method 942.05), crude protein (CP; method 981.10) and ether extract (EE; method 920.29) were performed according to the methodologies described by the Association of Official Analytical Chemists (AOAC 2016). Neutral detergent fiber (NDF) and Acid detergent fiber (ADF) were determined according to Van Soest, Robertson, and Lewis (1991). Lignin (LIG) was determined by treating acid detergent fiber residue with $72 \%$ sulfuric acid (Silva and Queiroz 2002) and the hemicellulose (HEM) and cellulose (CEL) fractions were estimated by the equations: $\mathrm{HEM}=\mathrm{NDFap}-\mathrm{ADF}$ and CEL $=\mathrm{ADF}-\mathrm{LIG}$, respectively (Silva and Queiroz 2002).

\section{Statistical analyses}

The obtained data were evaluated by analysis of variance and polynomial regressions for the quantitative factor (water salinity); for the qualitative factor, organic fertilization, Student's t-test was used, both when there was significance in the F test. The data were analyzed by GLM procedure from SAS University, considering as significant probability values lower than $5 \%$.

\section{Results}

In first cut, the variables of number of leaves, number of dead leaves and proportion of dead material were influenced by the isolated effect of saline levels $(p<.05)$. In turn, the fresh mass production, dry mass production, plant height, leaf length, panicle length, leaf proportion, crude protein and ether extract were influenced by the isolated effect of saline water levels in second cut. There was no interaction $(p<.05)$ between applied saline water depths and organic matter levels for the variables studied in cuts first and second, except for the lignin variable, in second cut. For water use efficiency, there was no effect $(p>.05)$ for the treatments (irrigation depths and organic matter).

The number of leaves in first cut (Figure 2a) increased linearly $(p<.05)$ with saline water depths of $25 \%$ to $100 \%$ evapotranspiration. For the number of dead leaves, there was a linear reduction as the water supply increased (Figure $2 b$ ).

For plant height, leaf length, panicle length, in second cut (Figure 3), there was a positive linear effect; with the supply of the largest water depth $(100 \%$ ET) the highest values were obtained for these variables.

The percentage of dead material and leaves had an isolated effect $(p<.05)$ from the irrigation levels provided in the second cut (Figure 4). For the percentage of dead material, a decreasing linear behavior can be observed, with the lowest proportion of dead material with the supply of the largest water levels, $100 \%$ evapotranspiration.

A quadratic behavior, since the largest proportion of leaves in second cut occurred in the applied water level of 25 and $75 \%$ evapotranspiration, presenting 27.71 and $28.13 \%$, respectively (Figure $4 \mathrm{~b}$ ). 
(a)
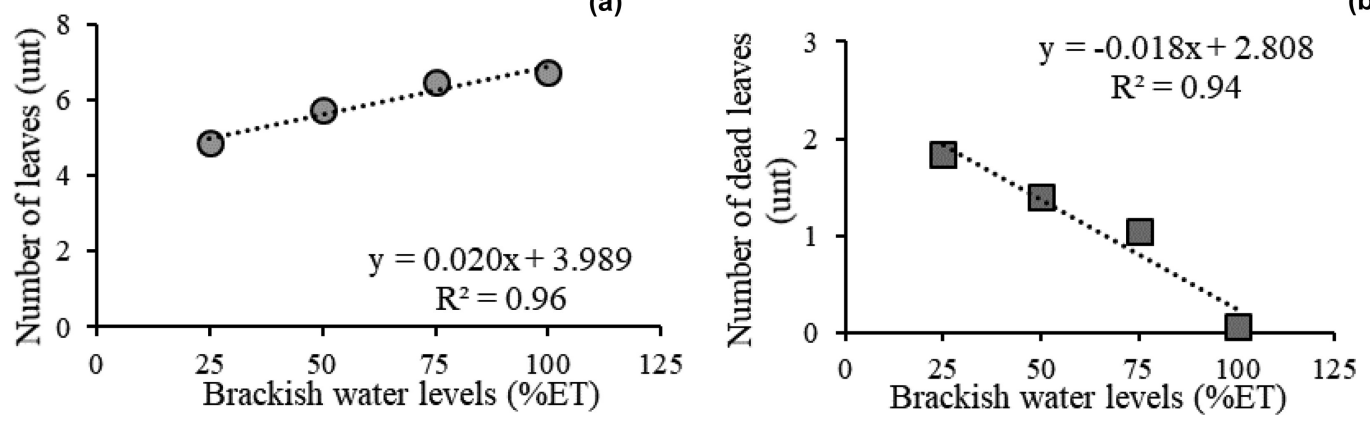

Figure 2. Number of leaves, number of dead leaves of pearl millet subjected to different brackish water irrigation levels in cycle 1.

(a)

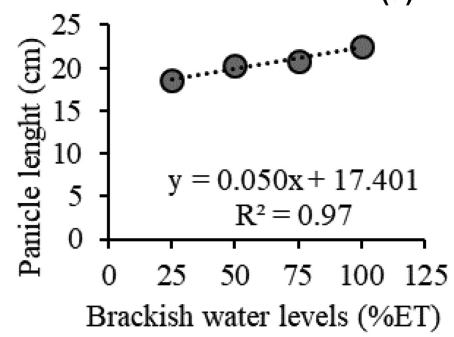

(b)

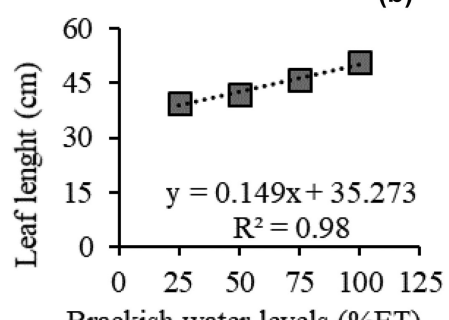

Brackish water levels (\%ET)

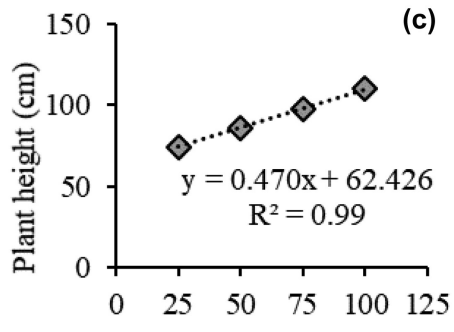

Brackish water levels (\%ET)

Figure 3. Panicle length, leaf length and plant height of millet subjected to different brackish water irrigation depths in cycle 2 .
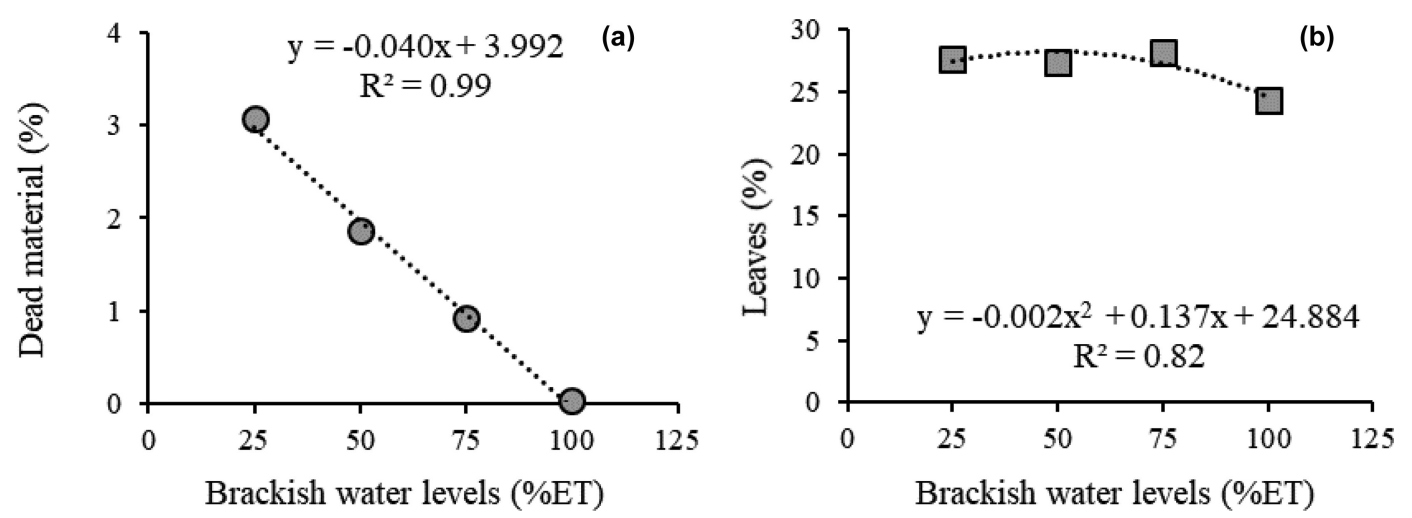

Figure 4. Percentage of dead material (a) and percentage of leaves (b) of pearl millet subjected to different brackish water irrigation levels per cut.

Fresh and dry matter production showed an increasing linear effect $(p<.05)$ with the application of brackish water levels (Figure 5).

In the chemical analysis, only in the second cut there was significance for the variables crude protein and ether extract; the other variables were not significant for the first cut (Table 3). Therefore, higher crude protein values (16.59 and 16.91\%) were found when smaller amounts of brackish water $(p<.05), 25$ and 50\% ET were provided (Table 3 ).

There was a significant interaction between applied brackish water levels and organic matter levels for the lignin content in second cut (Figure 6). The lignin content was higher in the treatment with 

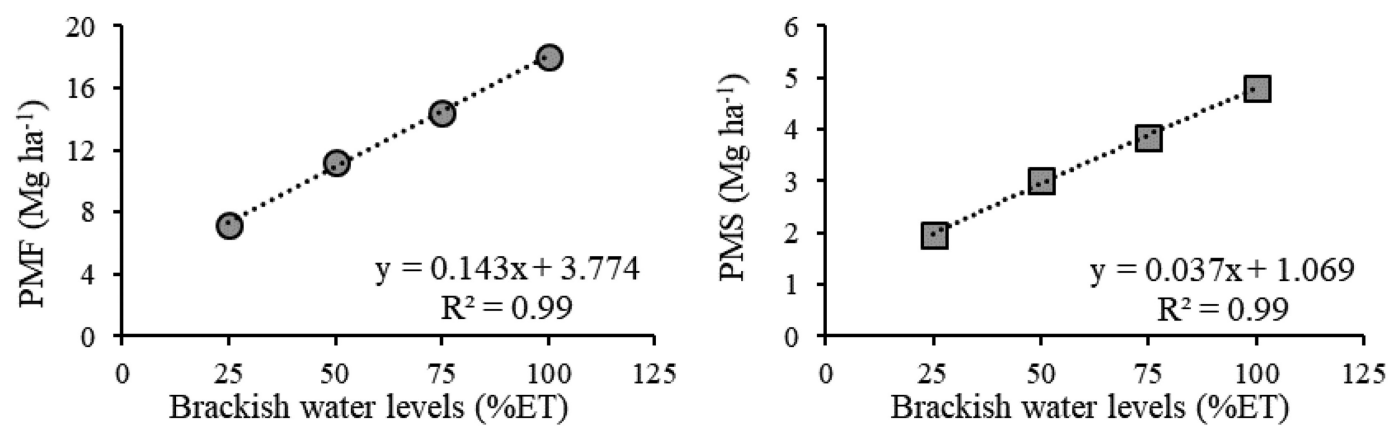

Figure 5. Fresh (PMF) (a) and dry (PMS) (b) matter production of pearl millet plants subjected to different brackish water irrigation levels per cut.

Table 3. Chemical composition of pearl millet according to brackish water irrigation levels.

\begin{tabular}{lrrrrrr} 
& \multicolumn{3}{c}{ Levels (\% Evapotranspiration) } & & \\
\cline { 2 - 5 } Variables & \multicolumn{1}{c}{25} & 50 & 75 & 100 & $P$ value & CV (\%) \\
\hline Cut 1 & 10.84 & 10.68 & 10.65 & 10.82 & .952 & 12.12 \\
Crude protein (in \% DM) & 2.63 & 2.47 & 2.81 & 2.17 & .378 & 35.59 \\
Ether extract (in \% DM) & 57.26 & 57.34 & 58.29 & 57.93 & .711 & 4.13 \\
Neutral detergente fiber (in \% DM) & 28.99 & 29.07 & 30.05 & 30.17 & .387 & 6.89 \\
Acid detergente fiber (in \% DM) & 24.89 & 25.16 & 25.75 & 26.03 & .354 & 6.46 \\
Cellulose (in \% DM) & 28.28 & 28.27 & 28.24 & 27.77 & .599 & 3.68 \\
Hemicellulose (in \% DM) & 27.32 & 27.63 & 25.94 & 25.14 & .148 & 10.70 \\
Dry matter (in \% NM) & 9.78 & 10.06 & 10.13 & 10.33 & .784 & 12.46 \\
Mineral matter (in \% DM) & & & & & \\
Cut 2 & 16.59 & 16.91 & 15.49 & 13.88 & .003 & 11.99 \\
Crude protein (in \% DM) ${ }^{\text {a }}$ & 2.35 & 2.17 & 1.77 & 1.977 & .036 & 26.08 \\
Ether extract (in \% DM) & 61.27 & 61.82 & 63.93 & 62.77 & .330 & 5.73 \\
Neutral detergente fiber (in \% DM) & 27.82 & 27.29 & 30.23 & 31.23 & .508 & 9.82 \\
Acid detergente fiber (in \% DM) & 24.70 & 24.21 & 26.48 & 27.18 & .589 & 10.48 \\
Cellulose (in \% DM) & 33.45 & 34.52 & 33.71 & 31.55 & .188 & 7.34 \\
Hemicellulose (in \% DM) & 27.66 & 27.15 & 26.77 & 26.73 & .611 & 6.75 \\
Dry matter (in \% NM) & 8.88 & 8.77 & 9.17 & 9.39 & .222 & 8.28 \\
Mineral matter (in \% DM) & & & & \\
\hline
\end{tabular}

$\mathrm{DM}=$ Dry matter; NM = Natural matter; $\mathrm{CV}=$ coefficient of variation; Significant at the $5 \%$ probability level; Equations:

${ }^{\mathrm{a}} \mathrm{Y}=-0.0003 \times 2+0.0357 \mathrm{x}+15.713, \mathrm{R}^{2}=0.98 ;{ }^{\mathrm{b}} \mathrm{Y}=0.000006 \mathrm{x} 2-0.0155 \mathrm{x}+2.9177, \mathrm{R}^{2}=0.98$

larger water levels (100\% ET) and lower organic fertilizer dose $\left(0\right.$ ton $\left.\mathrm{ha}^{-1}\right)$; lower contents were observed for the lowest water levels $\left(25 \%\right.$ ET) with the highest level of organic fertilizer $\left(45\right.$ ton $\left.^{-1}\right)$.

\section{Discussion}

According to Silva et al. (2015) and Souza et al. (2017), the largest water supply affects the vegetative growth, with direct influence on elongation, expansion, cell division and photosynthesis, which promotes an increase in plant height and stem diameter. Costa et al. (2015) reported that irrigation with water of $2.5 \mathrm{dS} \mathrm{m}^{-1}$ had no deleterious effect on the length and diameter of the ear.

The percentage of leaves in second cut was $24.31 \%$ lower when more brackish water was applied ( $100 \%$ ET) compared to the lower levels used (25\% ET), with a reduction of $12.23 \%$ between the highest and lowest percentage of leaves, showing a possible effect of salinity on dry matter deposition of leaves. The lowest percentage of leaves may have occurred due to higher plant height, due to the applied levels, consequently a higher proportion of stem (Taiz and Zeiger 2013). 


$$
\mathrm{LIG}=2.6326+0.0138 \mathrm{x}+00004 \mathrm{y}
$$

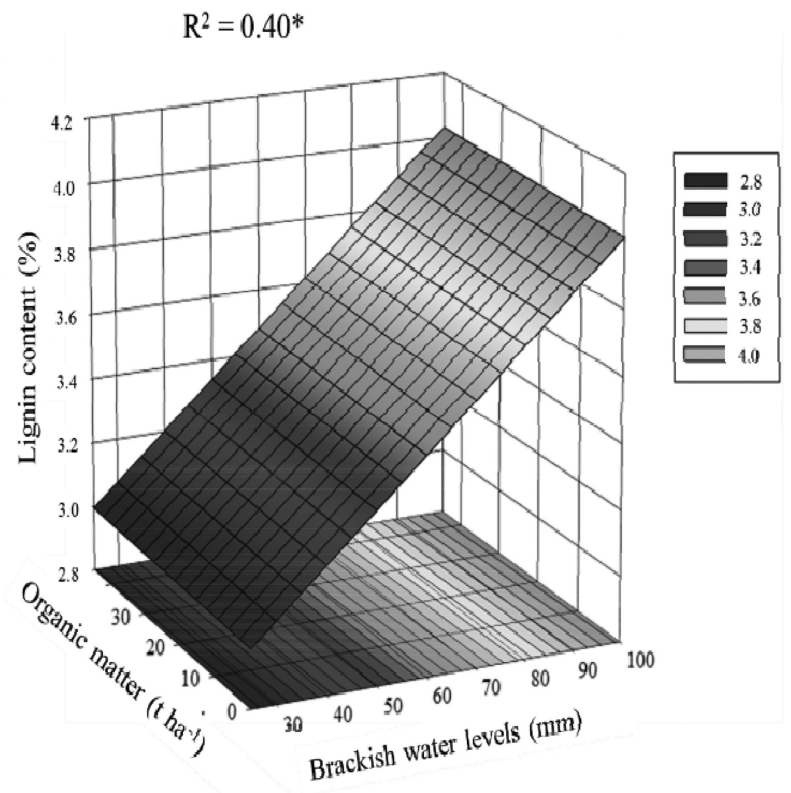

Figure 6. Lignin content of pearl millet plants subjected to different brackish water irrigation levels and different levels of organic matter fertilization.

Pearl millet has a xerophilic potential, that is, the ability to adapt to saline environments and due to the higher height, length of leaves and panicles and better water supply (Pereira Filho et al. 2003); differing from Conus et al. (2009), who found a reduction in shoot biomass accumulation in response to different salinity levels of irrigation water.

The reduction in crude protein with larger brackish water levels may be due to reductions in plant nitrogen acquisition or changes in the allocation and partition of assimilates within the plant (Wang et al. 2012).

A quadratic effect was found as more water was supplied, that is, the plant achieved higher height, but the number of live leaves did not increase proportionally to the stem length, which led to a slight reduction in the proportion of leaves. It can be deduced that there was no significant increase in leaf area and consequently in photosynthetic rate, thus reducing protein synthesis.

Even with a quadratic behavior, the highest ether extract content $(2.34 \%)$ was obtained when supplying a smaller amount of saline water, 25\% ETo, in cut 2 (Table 2). However, a higher panicle length was verified, but visually, smaller panicles contained more grains, which justifies the increase in fat content.

Lignin is of great importance for plant development. For Khan et al. (2015), lower lignin content in corn is associated with undesirable agronomic traits such as lower yield and higher susceptibility to stem lodging. According to Parizotto et al. (2015), excessive lignification may be undesirable, considering that this phenolic compound is related to the lower extensibility of cell walls, which may reduce plant growth. The mean values found in the present study are within the range indicated by Ribeiro Júnior et al. (2009) between 1.5 and 7.5\%.

According to Liu, Luo, and Zheng (2018), saline stress increased phenylalanine content in leaves, as it is a precursor of lignin, this could increase lignification. For Gohlizadeh and Kohnehrouz (2010), leaves of corn plants under saline stress had higher activity of the enzyme phenylalanine 
ammonia-lyase (PAL), which may favor lignin biosynthesis from phenylalanine, and according to Siqueira-Soares et al. (2013), cell wall lignification occurs concomitantly with higher PAL activity.

\section{Conclusion}

Brackish water and organic matter levels did not influence biomass production and chemical composition of pearl millet plants in first cut under minimum rainfall of 138.4 millimeters.

Growth, biomass production and chemical composition variables in the second cut are positively influenced by different brackish irrigation levels under low rainfall conditions.

Brackish water supplying $100 \%$ crop evapotranspiration is beneficial to pearl millet culture to obtain the second cut in low rainfall. This practice should take into account the minimum and seasonal use of this water based on the hydrological regime of each region associated with the use of organic matter as a way to remedy the effects of the use of these waters.

\section{Conflict of interest}

The authors declare that they have no competing interests.

\section{Funding}

This work was supported by the Coordination for the Improvement of Higher Education Personnel (CAPES-Brazil) and the Brazilian Agricultural Research Corporation (EMBRAPA Semiarid).

\section{ORCID}

Jaciele Beserra de Lira (D) http://orcid.org/0000-0003-4719-2911

Alberício Pereira de Andrade (D) http://orcid.org/0000-0002-1223-394X

André Luiz Rodrigues Magalhães (D) http://orcid.org/0000-0003-2211-6795

Fleming Sena Campos (D) http://orcid.org/0000-0001-9027-3210

Gherman Garcia Leal de Araújo (D) http://orcid.org/0000-0001-9605-1096

Glayciane Costa Gois (D) http://orcid.org/0000-0002-4624-1825

Amadeu Regitano Neto (D) http://orcid.org/0000-0002-7774-8151

Diego de Sousa Cunha (D) http://orcid.org/0000-0003-0034-3487

José Nildo Tabosa (D) http://orcid.org/0000-0002-0759-8071

Thieres George Freire da Silva (D) http://orcid.org/0000-0002-8355-4935

Hideo de Jesus Nagahama (D) http://orcid.org/0000-0002-7664-5118

\section{References}

Association of Official Analytical Chemists (AOAC). 2016. Official methods of analysis of AOAC International. ed. Latimer Jr., G.W. 20th ed., 3100. Washington, D.C..

Conus, L. A., P. C. Cardoso, L. D. R. Venturoso, and S. D. P. Q. Scalon. 2009. Seed germination and vigor of corn plants submitted to saline stress induced by different salts. Revista Brasileira de Sementes 31:67-74. doi:10.1590/ S0101-31222009000400008.

Costa, J. P. N., E. G. Cavalcante Junior, J. F. Medeiros, and R. A. A. Guedes. 2015. Evapotranspiration and corn yield the blades and different salinity of irrigation water. Irriga 1:74-80. doi:10.15809/irriga.2015v1n2p74.

Ertek, A., S. Sensoy, and I. Gedik. 2006. Irrigation scheduling based on pan evaporation values for cucumber (Cucumis sativus L.) grown under field conditions . Agricultural Water Management 81:159-72. doi:10.1016/j. agwat.2005.03.008.

Gohlizadeh, A., and B. B. Kohnehrouz. 2010. Activation of phenylalanine ammonia-lyase as a key component of the antioxidative system of salt-challenged maize leaves. Brazilian Journal of Plant Physiology 22:217-23. doi:10.1590/ S1677-04202010000400001.

Gois, G. C., A. G. S. Matias, G. G. L. Araújo, F. S. Campos, W. L. Simões, F. N. Lista, M. J. M. Guimarães, T. S. Silva, A. L. R. Magalhães, and J. K. B. Silva. 2019. Nutritional and fermentative profile of forage sorghum irrigated with saline water. Biological Rhythm Research 50:1-12. doi:10.1080/09291016.2019.1629088. 
Khan, N. A., P. Yu, M. Ali, J. W. Cone, and W. H. Hendriks. 2015. Nutritive value of maize silage in relation to dairy cow performance and milk quality. Journal of the Science of Food and Agriculture 95:238-52. doi:10.1002/jsfa.6703.

Liu, Q., L. Luo, and L. Zheng. 2018. Lignins: Biosynthesis and biological functions in plants. International Journal of Molecular Medical Science 19:1-16. doi:10.3390/ijms19020335.

Moura, M. M. A., D. A. A. Pires, D. G. Jayme, R. F. Costa, J. P. S. Rigueira, and J. A. S. Rodrigues. 2018. Agronomic performance and nutritive value of millet silages. Acta Scientiarum Animal Sciences 40:e34430. doi:10.4025/ actascianimsci.v40i1.34430.

Parizotto, A. V., G. A. Bubna, R. Marchiosi, A. R. Soares, M. L. L. Ferrarese, and O. Ferrarese-Filho. 2015. Benzoxazolin-2(3H)-one inhibits soybean growth and alters the monomeric composition of lignin. Plant Signaling \& Behavior 10:e989059. doi:10.4161/15592324.2014.989059.

Pereira Filho, I. A., A. D. S. Ferreira, A. M. Coelho, C. R. Casela, D. Karam, J. A. S. Rodrigues, J. C. Cruz, and J. M. Waquil. 2003. Manejo da cultura do milheto. 29th ed. Embrapa Milho e Sorgo-Circular Técnica.

Ribeiro Júnior, G. D. O. R., L. C. Gonçalves, R. G. Júnior, F. P. Pôssas, and R. M. Maurício. 2009. Pearl millet as an option for dairy cattle. In Alimentos para Gado de Leite, ed. L. C. Gonçalves, I. Borges, and P. D. S. Ferreira, Vol. 5, 65-87. Belo Horizonte: FEPMVZ, cap.

Richard, L. A. 1954. Diagnosis and improvement of saline and alkali soils. Agricultural handbook. 60th ed. Washington, DC: USDA.

Santos, H. G., P. K. T. Jacomine, L. H. C. Anjos, V. A. Oliveira, J. F. Lumbreras, M. R. Coelho, J. A. Almeida, T. J. F. Cunha, and J. B. Oliveira. 2013. Sistema brasileiro de classificação de solos. 3th ed. Brasília: Embrapa.

Shrivastava, P., and R. Kumar. 2015. Salinity: A serious environmental issue and plant growth-promoting bacteria as one of the tools for its alleviation. Saudi Journal of Biological Sciences 22:123-31. doi:10.1016/j.sjbs.2014.12.001,.

Silva, D. J., and A. C. Queiroz. 2002. Análise de alimentos: Métodos químicos e biológicos, 235. 3rd ed. Viçosa, MG: UFV.

Silva, J. L. A., J. F. Medeiros, S. S. Alves, F. A. Oliveira, M. J. Silva Junior, and I. B. Nascimento. 2015. Use of saline waters as an alternative for irrigation and production of fodder in the northeastern semiarid region. Revista Brasileira De Engenharia Agrícola E Ambiental 18:66-72. doi:10.1590/1807-1929.

Siqueira-Soares, R. C., A. R. Soares, A. V. Parizotto, M. L. L. Ferrarese, and O. Ferrarese-Filho. 2013. Root growth and enzymes related to the lignification of maize seedlings exposed to the allelochemical L-DOPA. The Scientific World Journal 2013:1-6. doi:10.1155/2013/134237.

Sjoerd, E. A. T. M., Z. van der, S. F. Stofberg, X. Yang, Y. Liu, M. N. Islam, and Y. F. Hu. 2017. Irrigation and drainage in agriculture: A salinity and environmental perspective. In Current perspective on irrigation and drainage, Suren Kulshreshtha and Amin Elshorbagy, Chapter 1, 1-23. IntechOpen.

Souza, P. G. R., T. V. A. Viana, C. M. Carvalho, A. M. Sousa, C. P. M. Costa, and B. M. Azevedo. 2017. Effect of different grounds of irrigation and soil coverage on the growth of sorghum culture. Revista Brasileira de Agricultura Irrigada 11:1528-37. doi:10.7127/rbai.v11n400592.

Taiz, L., and E. Zeiger. 2013. Fisiologia vegetal. 5th ed. Porto Alegre: Artmed.

Taiz, L., E. Zeiger, I. M. Møller, and A. Murphy. 2017. Plant physiology and development. 6th ed. Porto Alegre: Artmed.

Toderich, K., E. Shuyskaya, Z. Rakhmankulova, R. Bukarev, T. Khujanazarov, R. Zhapaev, S. Ismail, S. K. Gupta, N. Yamanaka, and F. Boboev. 2018. Threshold tolerance of new genotypes of Pennisetum glaucum (L.) R. Br. to salinity and drought. Agronomy 8:1-13. doi:10.3390/agronomy8100230.

Travassos, K. D., H. R. Gheyi, H. M. M. Barros, F. A. L. Soares, C. A. Uyedal, N. S. Dias, M. G. Tavares, and R. Chipana-Rivera. 2019. Water consumption of the sunflower crop irrigated with saline water. DYNA 86:221-26. doi:10.15446/dyna.v86n208.73203.

Van Soest, P. J., J. B. Robertson, and B. A. Lewis. 1991. Methods for dietary fiber, neutral detergent fiber, and non-starch polysaccharides in relation to animal nutrition. Journal of Dairy Science 74:3583-97. doi:10.3168/jds. S0022-0302(91)78551-2.

Wang, M., S. Shi, F. Lin, Z. Hao, P. Jiang, and G. Guanhua Dai. 2012. Effects of soil water and nitrogen on growth and photosynthetic response of Manchurian ash (Fraxinus mandshurica) seedlings in Northeastern China. PloS One 7: e30754. doi:10.1371/journal.pone.0030754. 